16. Edmunds, W. M., Walton, N. R. G., A geochemical and isotope approach to recharge evaluation in semi-arid zones-past and present. IAEA, Application of Isotope techniques in Arid Zone $\mathrm{H}$ drology, Proc. Advisory Group Meeting, Vienna, 1978, 47-68.

17. Allison, G. B., Hughes, M. W., The use of environmental chloride and tritium to estimate total recharge of an unconfined aquifer, Aust. J. Soil Res., 1978, 16: 181-195.

18. Edmunds, W. M., Gaye, C. B., Fontes, J. C., A record of clim atic and environmental change contained in interstitial waters from the unsaturated zone of northern Senegal, In Isotope Techniques in Water Resources Development 1991, Proceedings, Symposium of the IAEA, Vienna: IAEA, 1992, 533-549.

19. Cook, P. G., Edmunds, W. M., Gaye, C. B., Estimating paleorecharge and paleoclimate from unsatured zone profiles, Water Resour. Res., 1992, 28: 2721-2731.

20. Zhu, Z., Desert and Desertification Rehabilitation in China, Beijing: Chinese Environmental Science Press, 1999, 137-142.

21. Zhang, J., Lin, Z., Climate of China, New York: Wiley, 1992.

22. Darling, W. G., Talbot, J. C., Extraction method for the isotopic analysis of porewaters. Rep. WD/89/66,British Geological Survey, England: Wallingford, 1989, 13.

23. Tandia, A. A., Revue critique des methods d' evaluation de la echarge des nappes. Contribution de approche geochemique et isotopique, Louga Nord Senegal, University of Daker, 1990, 138.

24. Barnes, C. J., Allison, G., The distribution of deuterium and ${ }^{18} \mathrm{O}$ in dry soil, 1.Theory, J. Hydrol., 1983, 60: 141-156.

25. Edmunds, W. M., Gaye, C. B., Kinniburgh, D. G., Solute profile techniques for recharge estimation in semi-arid and arid terrain, in Estimation of Natural Groundwater Recharge (ed. Simmers, I.), Dordrecht: Reidel, 1988,136-157.

26. Yao, T., Qing, D., Tian, L. et al., Temperature and precipitation fluctuations in Tibetan Plateau during the last 2000 years: record in Guliya ice core, Science in China, Ser. D, 1996, 26(4): 348 353.

27. Shi, Y., Yao, T., Yang, B., 10 a scale climatic change during the last 2000 a recorded in Guliya ice core and compared to East China references records, Science in China, Ser. D, 1999, 29: 79-86.

28. Zhang, P., The Climatic Change in China, Jinan: Shandong Scientific and Technique Press, 1996, 231-436.

29. Shi, Y. F., Zhang, X. S., The influence of climate changes on the water resources in the arid areas of northwest China, Science in China, Ser. B, 1995, 25: $968-977$.

30. Chen, L., Shao, Y., Zhang, Q., The research on climatic change during the recent 40 a, J. Application Meteorology, 1991, 2(2): $164-173$.

31. Herczeg, A. L., Edmunds, W. M., Inorganic ions as tracers in Environmental Tracers in Subsurface Hydrology, CSIRO Land and water (eds. Cook, P. G., Herczeg, A. L.), Glen Osmond, Austrilia, 2000, 31-76.

(Received June 6, 2002; accepted April 7, 2003) Chinese Science Bulletin 2003 Vol. 48 No.14 1474-1479

\section{Temperature and precipitation in Mongolia based on dendroclimatic investigations}

\author{
G. Jacoby, N. Pederson \& R. D’ Arrigo \\ Lamont-Doherty Earth Observatory, Palisades, NY 10964, USA
}

Abstract Recent tree-ring studies in Mongolia provide e vidence of unusual warming that is in agreement with largescale reconstructed and recorded temperatures for the Northern Hemisphere and the Arctic. One Mongolian proxy record for temperature extends back over 1000 years and several others are over 350 years in length. Precipitation reconstructions based on tree rings reflect recent increases but also indicate that the increases are within the long-term range of variations. Spectral analyses of recorded precipitation data and the reconstructions support the hypotheses of quasi-solar periodicity in precipitation variation, previously suggested by others.

Keywords: tree rings, Mongolia, paleoclimate, climatic change.

\section{DOI: 10.1360/02wd0390}

Central Asia has relatively few extended records of paleoclimatic data. The agrarian resources of this region are strongly influenced by extreme temperatures and limited water availability. The longer records that tree-ring studies produce could be useful for regional planning and also provide information about the region for incorporation in larger-scale, hemispheric, climatic analyses. The climate of Mongolia is dominated by advected air masses although in summer local radiation balances and convective storms also influence precipitation and temperatures. The recorded climatic data are rather short with few meteorological or hydrological records extending back past the 1940s. The Mongolian-American Tree-Ring Project (MATRIP) engages in paleoclimate studies in Mongolia and related regions in China and Russia. This paper is a brief report on the current findings of MATRIP in Mongolia. These MATRIP studies provide better and more extended climatic information for the country and for the region.

Initial tree-ring studies in Mongolia started in the 1980 s with some of the first reports published in the 1980 s and early 1990s (e.g. Lovelius et al. ${ }^{[1]}$ ). Many of these studies are in Russian and Mongolian and are not readily available. MATRIP was started in 1995 and field collection of samples or teaching have taken place in most years since then. The first paper describing the MATRIP results came out in $1996^{[2]}$ and a more intensive phase of the project began in 1997. The collections to date extend 


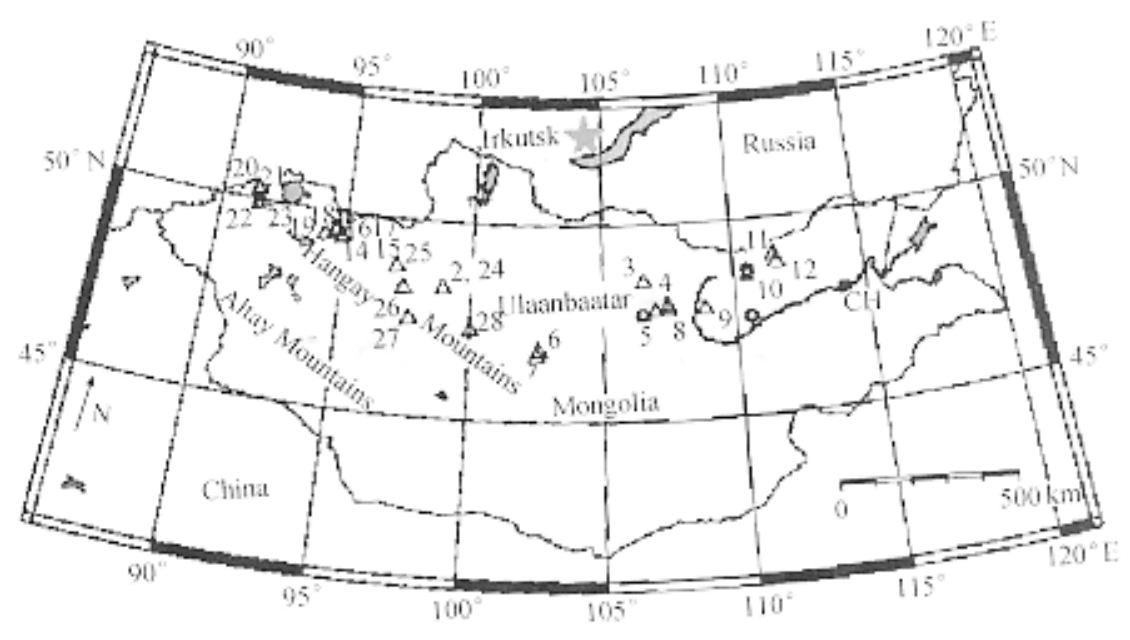

Fig. 1. Map of MATRIP tree-ring sample collection sites in Mongolia. The numbers correspond to site numbers in the text.

from four sites at elevational treeline down to four lower forest border sites, where the trees end and grasslands begin. The highest sampling location is a mesic site at treeline in the Tarvagatay Mountains where the dominant limiting factor to growth is temperature ${ }^{[2]}$. One other upper treeline site is a drier location above Lake Hovsgul where both moisture and temperature influence tree growth. Three sampling sites are at or very near the lower limit of tree growth where moisture is the dominant limiting factor to growth. There are several sites at intermediate locations. All the collection sites are in central or western Mongolia (Fig. 1).

The three main species we have sampled and found useful are Siberian pine (Pinus sibirica Du Tour), Scots pine (P. sylvestris L.), and Siberian larch (Larix sibirica Ledebour). We tried to find sites with the least evidence of human disturbance. There was evidence of fire in three of the sites where we sampled Scots pine. We sampled by avoiding areas on the trunk near burn scars and there seemed to be little effect in most of the cores and resulting ring-width series. With its thick bark, the mature Scots pines are relatively resistant to fire damage. The larch specimens also have some problems. There is a serious heart-rot problem and at some sites with old-aged trees it is difficult to find trees that yield solid cores extending to the central rings. Also, we have observed anatomical symptoms in larch that may indicate tree damage due to insects. The xylem cell patterns are similar to those described by Weber ${ }^{[3]}$ for damage by larch budmoth to trees in Switzerland. This potential problem is being investigated further to see the effect on trees and the ring-width series.

\section{Temperature}

Previous analyses of recorded temperatures by
Dagvadorj and Mijiddor ${ }^{[4]}$ showed increases for fall, winter and spring temperatures but decrease in summer temperature for the 1940 to 1995 period. Dagvadorj and Mijiddorj also note the following changes in the recorded temperatures: winter heating degree days are less, the growing season is longer by about 10 to 20 days due to the warmer spring and fall, the extreme heat in summer is less, and annual temperatures have increased by about 1.8 $\mathrm{T} \mathrm{C}$ in western Mongolia, 1.0 $\mathrm{C}$ in central Mongolia, and $0.3^{\top} \mathrm{C}$ in eastern Mongolia. A comparison between annual temperatures for Mongolia and the northern hemisphere show that the trends in Mongolia reflect the same general trends.

At one location we collected many pieces of relict wood along with cores from the old-aged living Siberian pine trees. The resulting chronology extends back to 262 AD (Fig. 2) ${ }^{[5]}$.

Replication is one of the essential requirements for confirming dendroclimatic records. We included three other high-elevation tree-ring records from our Mongolian sites and, using principal component analysis $(\mathrm{PCA})^{[6]}$, generated a time series based on the first eigenvector of the four tree-ring series. This series was compared statistically and graphically with two other proxy temperature series $^{[7]}$ (Fig. 3).

The low frequency trends in the Mongolian time series correspond very well graphically with the other two series and the correlations are 0.67 and 0.47 with a Northern Hemisphere temperature reconstruction (modified from Jacoby and D' Arrigo ${ }^{[8]}$ and one described by Mann et al. ${ }^{[9]}$, respectively).

\section{Precipitation and streamflow}

Significant recent changes in precipitation and 


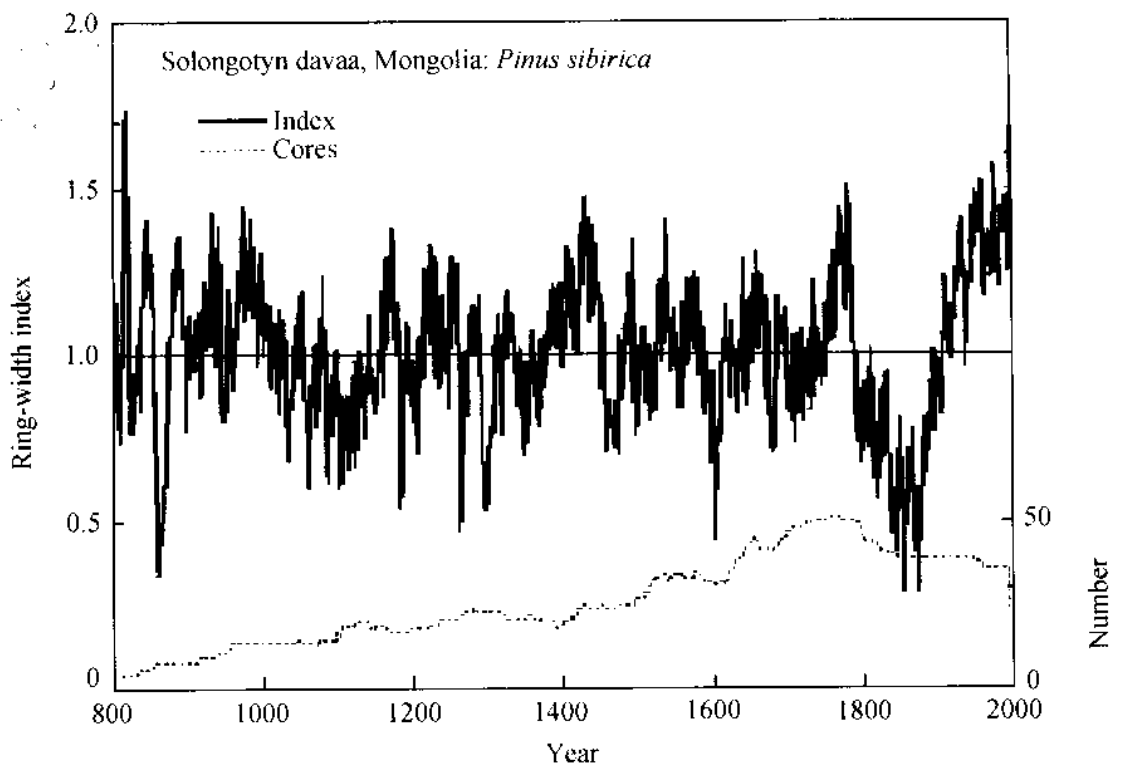

Fig. 2. Plot of the ring-width indices from the Solongotyn Davaa site.

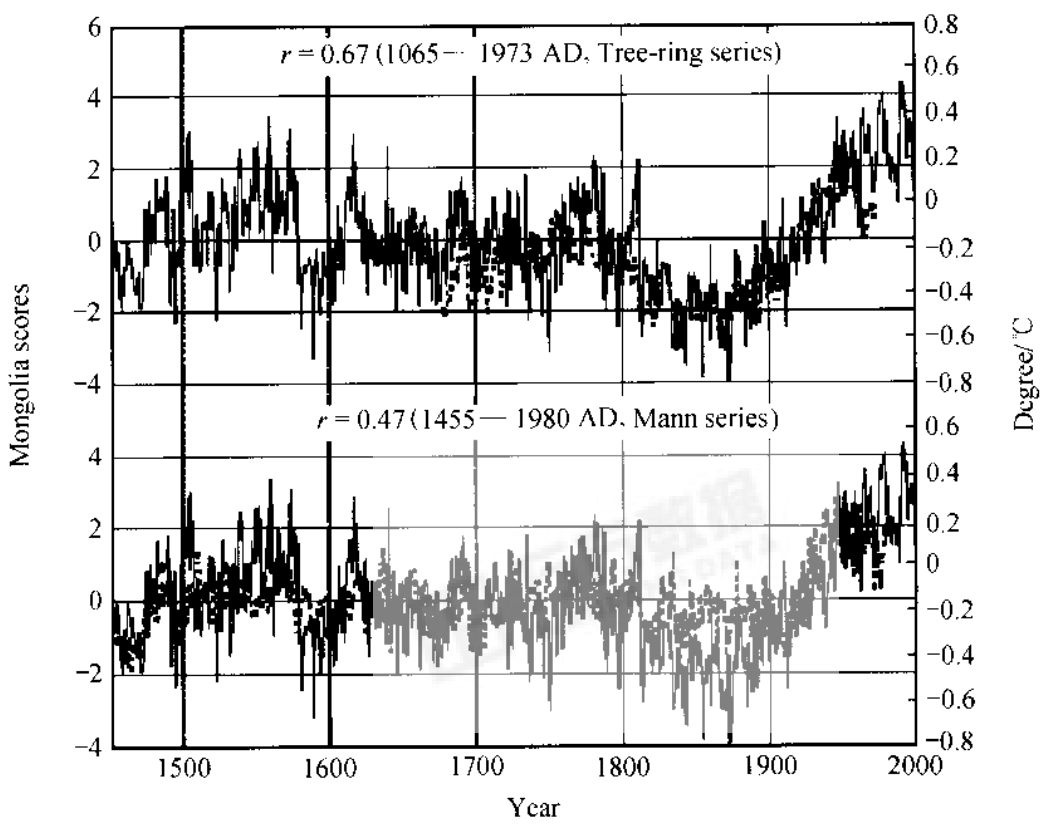

Fig. 3. Plots of the first eigenvector from four temperature-sensitive, treeline sites (solid lines) with two Northern Hemisphere temperature reconstructions (dashed lines).

streamflow have occurred for central Mongolia. The recorded data from 1940 to present show an increase in total annual precipitation, compatible with precipitation trends estimated by GCMs. Two of the ring-width chronologies from moisture-sensitive, lower forest border sites were used to make reconstructions of precipitation and streamflow (other sampling data not finalized). We developed monthly precipitation series for central Mongolia by com- bining data from eight precipitation gage stations. Missing values were estimated using data from the next nearest station. The combining of stations reduces the noise that may be present in a single station ${ }^{[10]}$ and is more representative of an area being studied. The streamflow data are from one station, Kherlen River near Choibalsan (Fig. $1, \mathrm{CH}$.). The associated drainage basin includes the Urgun Nars tree-ring site and the Zuun Mod site is justoutside 
the western edge of the basin. In the recorded data, the drought of 1944 was the most severe and there is a general trend upward since then until the past three years. This year is also the most extensive drought of the 20th century in the record reconstructed from historical information by Mijiddorj and Namhay ${ }^{[1]}$.

The tree-ring data from Urgun Nars (Fig. 1, 10) in east central Mongolia had the highest variance explained by monthly precipitation data. The sampled species is Scots pine. Using the data from January of the prior year through October of the current or growth year, precipitation could explain $58 \%$ of the tree-ring variation using the $1941-1995$ period. The standard chronology from AR$\mathrm{STAN}^{[12]}$ was used in the modeling. Correlations with monthly precipitation indicated a positive response to mid-summer to fall precipitation of the prior year and to spring and summer of the current year. Results were similar for the other moisture-stress tree-ring data from a location called Zuun Mod (Fig. 1,8) in central Mongolia. The trees atZuun Mod are Siberian larch. The variance explained by the precipitation data is $46 \%$ for the same $1941-1995$ period. Merging of the two series by PCA produces a single series that has $61 \%$ of its variance explained by the precipitation data. This first eigenvector series was then used as the predictor for precipitation and streamflow.

The annual precipitation for a year extending from prior July to current June was estimated using the first eigenvector as a predictor. The model included ring-width indices for the current year and for the following year because the correlations indicated the effect of prior year precipitation on the next year's growth (Fig. 4).

The model explained $57 \% R^{2}$ after adjusting for degrees of freedom lost due to the regression) of the variation in annual precipitation for the July through June period. Due to the shortness of the meteorological record, calibration-verification analyses were not performed. The reconstruction is shown in Fig. 5(a).

The Kherlen River streamflow near Choibalsan (Fig. 1, CH.) also shows good correlations with the tree-ring data. There is a seasonal shift towards higher correlations later in the year compared to the precipitation results. Much of this shift may be due to the lag between precipitation in the central mountains and the streamflow to the east. Based on the individual monthly correlations, models were made for annual flow from prior August through current July and summer flow from April through August of the growth year. The best models used only the first eigenvector for the annual flow. Adding in lagged treering data did not improve the models as it did for the

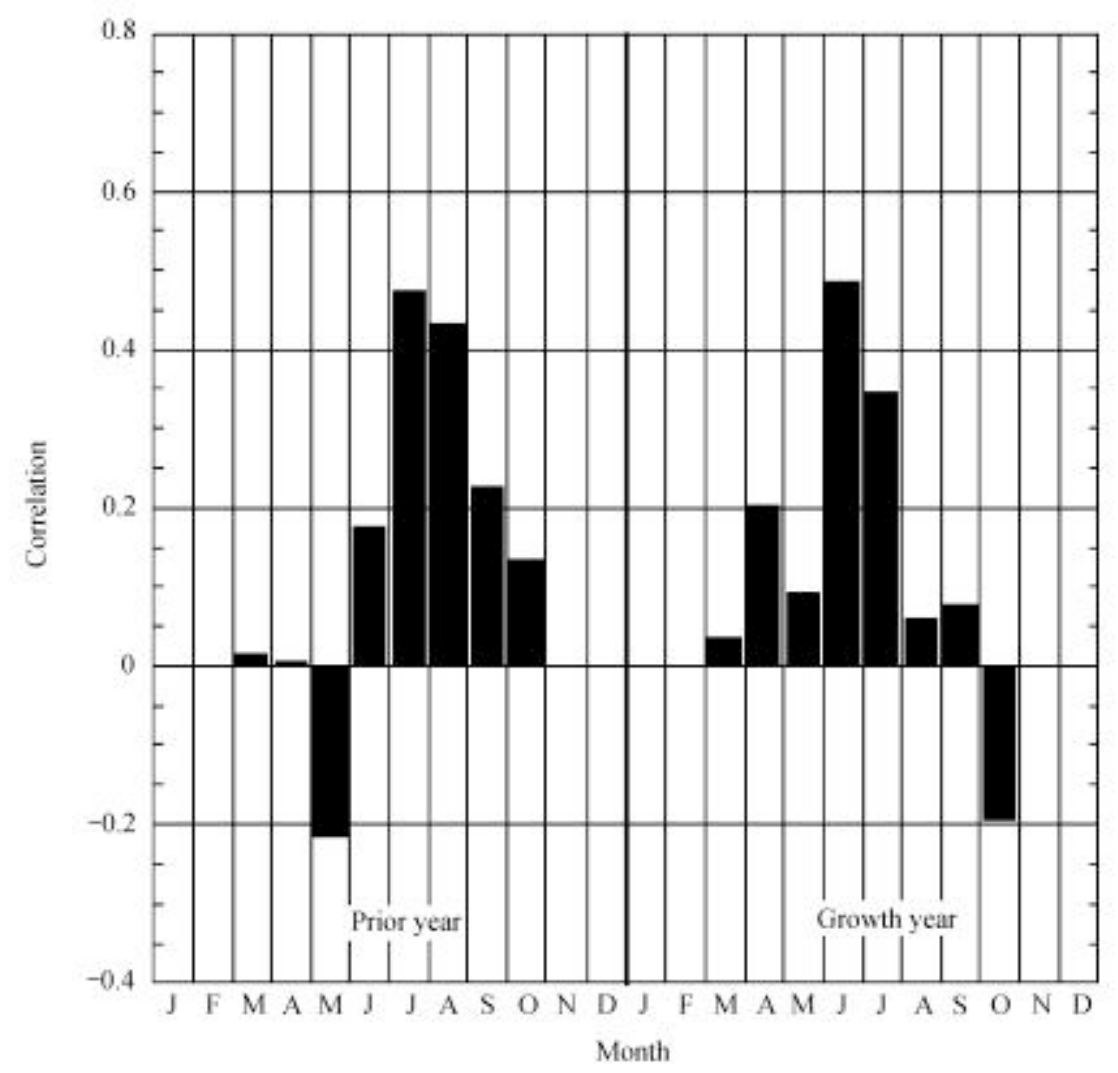

Fig. 4. Correlations between monthly mean temperatures and the first eigenvector from two moisture stress sites in Mongolia. 

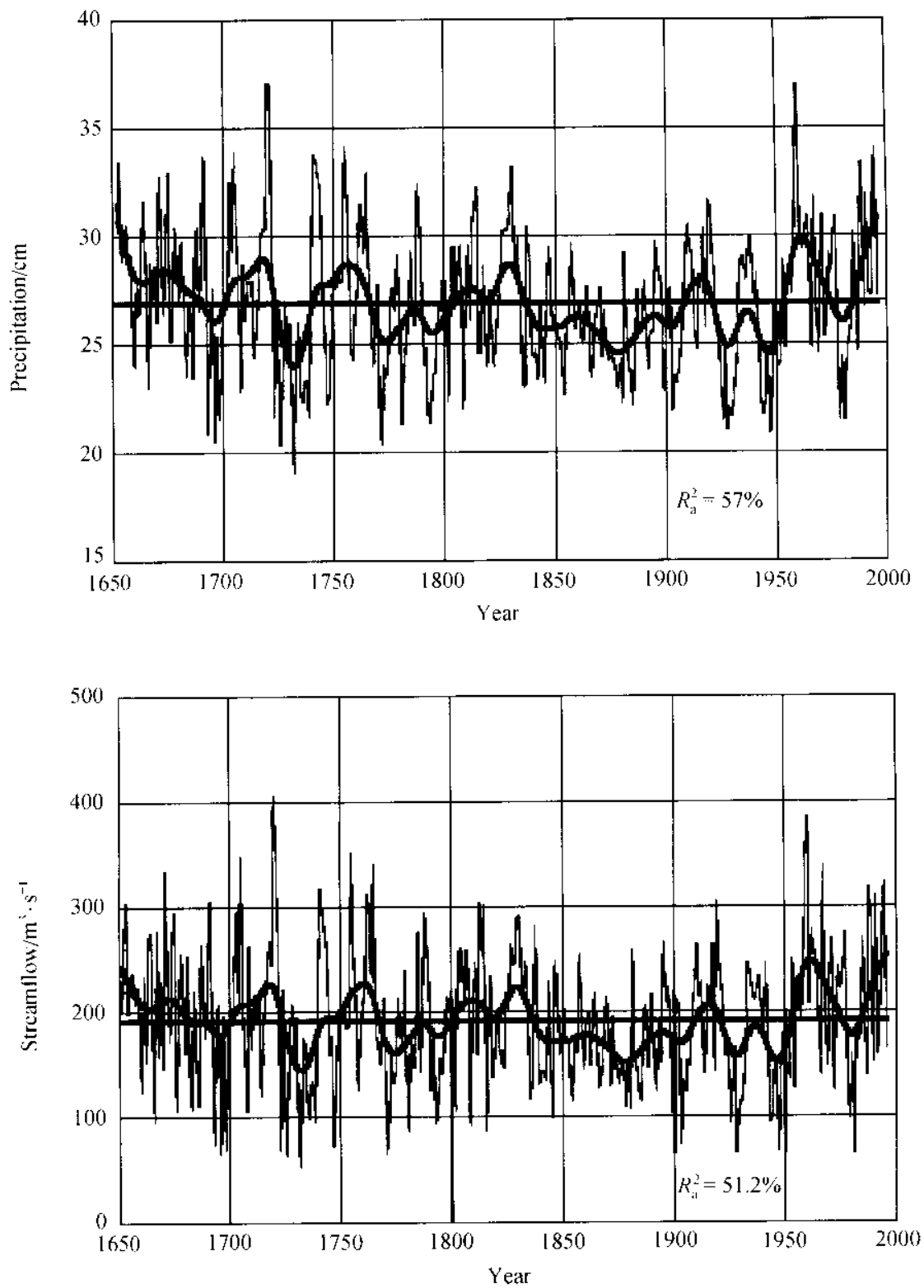

Fig. 5. Reconstructions of precipitation in east-central Mongolia (top) and streamflow at the Kherlen River gaging station (bottom).

precipitation reconstruction. The tree-ring data explained $51.2 \%$ of the variance for annual streamflow and $38.6 \%$ for summer flow. The annual flow reconstruction is shown in Fig. 5.

Both the precipitation and streamflow reconstructions are in agreement in the 1920 s when both tree-ring reconstructions and the historical reconstruction show severe drought ${ }^{[11]}$. The reconstruction shows a mild drought in the 1820 s but not as severe a drought as that shown in the historical reconstruction in the 1820 s, especially 1827 . The tree-ring reconstruction is for central and east central Mongolia whereas the historical reconstruc- tion is for all Mongolia. Therefore some of the differences may be due to different geographical coverage. More treering reconstructions are needed before full comparisons can be made.

\section{Spectral analyses}

Some earlier studies indicated quasi-solar periodicities in Mongolian tree-ring data (e.g. Lovelius et al. ${ }^{[1]}$ ) and drought $^{[11]}$. Our analyses indicate that periodicities are very dependent on the tree response to climate. Temperature-sensitive trees as represented by the Sol Dav site trees have very low periodicities. The trees from moisture sen- 
sitive sites show much more spectral power indicating periodicities in the solar ranges $(23.8-20.3,12.8,10.8$ year range) and 3.6-2.1-year range ${ }^{[13]}$. The quasi-solar periodicities in moisture-stressed trees and in drought occur in analyses of tree-ring data and drought in the coterminous United States of America ${ }^{[14]}$ and were previously proposed by A. E. Douglas ${ }^{[15]}$. Quasi-solar periodicities attract much discussion for two reasons. They indicate a response to solar activity and also confer some predictability of drought occurrence. The periodicity also attracts much criticism because a full mechanism is yet to be presented for the quasi-solar influence, although there are a few theoretical mechanisms ${ }^{[16,17]}$. All the spectral properties of the Mongolian tree-ring series warrant further investigation and interpretation beyond the scope of this paper.

\section{Conclusions}

The main conclusions of these initial studies are: (1) There is evidence of climatic change in Mongolia and temperature trends are in agreement with hemispheric trends towards warming in the 20th century. (2) Precipitation has been increasing in recent decades (except for drought of recent years) but is within the range of longterm variations. The variations appear to have a periodicity similar to solar variability. (3) Tree-ring analysis can be of great value in extending the climatic records for Mongolia.

Acknowledgements This research was aided by the Department of Forestry, Faculty of Biology, National University of Mongolia, the Ministry for Nature and the Environment of Mongolia, the Hydromet eorological Research Institute, and the Institute of Biological Sciences. The research was supported by the United States National Science Foundation, Paleoclimate Program (Grant No. ATM96-31750) and Earth System History (Grant No. ATM01-17442). The opportunity to present these results was aided by CAEP, National Lab. of Western China's Environmental Systems, College of Earth \& Environment Sciences, Lanzhou University, China. Lamont Contribution No. 6433.

\section{References}

1. Lovelius, N. V., Davaajamts, Ts., Gunin, P. D., Dendroindications of Forest Growth Conditions in Mongolia and Possibilities of Forecasting (in Russian), Russian Academy of Sciences, Moscow: Puschino, 1992, 32-49.

2. Jacoby, G. J., D’ Arrigo, R. D., Davaajamts, Ts., Mongolian tree rings and 20th-century warming, Science, 1996, 273: 771 $\longrightarrow 773$.

3. Weber, U. M., Dendroecological reconstruction and interpretation of larch budmoth (Zeiraphera diniana) outbreaks in two central alpine valleys of Switzerland from 1470—1990, Trees, 1997, 11: $277-290$.

4. Dagvadorj, D., Mijiddorj, R., Climate change issues in Mongolia,
79-88 in Hydrometeorological Issues in Mongolia (eds. Dagvadorj, D., Natsagdorj L.), Papers in Hydrometeorology, Ulaanbaatar, 1996, 230 .

5. D’ Arrigo, R., Jacoby, G. C., Frank, D. et al., 1738 years of Mongolian temperature variability inferred from a tree-ring record of Siberian pine, Geophys. Res. Lett., 2001, 28: 543-546.

6. Cook, E. R., Kairiukstis, L. A. (eds.), Methods of Dendrochronology, London: Kluwer Academic Publishers, 1990, 394.

7. D’ Arrigo, R. D., Jacoby, G., Pederson, N. et al., Mongolian tree rings, temperature sensitivity and reconstructions of Northern Hemisphere temperature, Holocene, 2000, 10(6): 669-672.

8. Jacoby, G. J., D’ Arrigo, R. D., Reconstructed Northern Hemisphere annual temperature since 1671 based on high-latitude treering data from North America, Climatic Change, 1989, 14: 3959.

9. Mann, M., Bradley, R., Hughes, M., Northern Hemisphere temperatures during the past millennium: inferences, uncertainties, and limitations, Geophys. Research Letters, 1999, 26: 759.

10. Blasing, T. J., Duvick, D. N., West, D. C., Dendroclimatic calibration and verification using regionally averaged single station precipitation data, Tree-Ring Bull., 1981, 41: 37-44.

11. Mijiddorj, R., Namhay, A., On drought and unfavorable winter conditions recurrence in Mongolia (in Russian), Transactions of the HMRI, Ulaanbaatar, 1983, 11: 118 - 131.

12. Cook, E. R., A time series analysis approach to tree-ring standardization, Ph.D. Thesis, Univ. of Arizona, Tucson, Arizona, reprinted at Lamont-Doherty Earth Observatory, Palisades, New York, 1985, 1-171.

13. Pederson, N., Jacoby, G. C., D’ Arrigo, R. D. et al., Hydrometeorological reconstructions for Northeastern Mongolia derived from tree rings: $1651-1995$, Journal of Climate, 2001, 14: 872881 .

14. Cook, E. R., Meko, D. M., Stockton, C. W., A new assessment of possible solar and lunar forcing of the bidecadal drought rhythm in the western United States, Journal of Climate, 1997, 10: 13431356.

15. Douglas, A. E., Climatic Cycles and Tree-Growth: A Study of the Annual Rings of Trees in Relation to Climate and Solar Activity, Washington: Carnegie Institution of Washington, 1919, 127.

16. Hoyt, D. V., Shatten, K. H., Rainfall, The Role of the Sun in Climate Change (eds. Hoyt, D. V., Schatten, K. H.), Oxford: Oxford University Press, 1997, 125-142.

17. Shindell, D., Rind, D., Balachandran, N. et al., Solar cycle variability, ozone, and climate, Science, 1999, 284: 305-308.

(Received July 29, 2002; accepted April 7, 2003) 